\title{
Efficacy of thymoquinone in the treatment of experimental lipopolysaccharide-induced acute lung injury
}

\author{
Mustafa Çolak ${ }^{1}$, Serdar Kalemci², Aylin Özgen Alpaydın ${ }^{1}$, Volkan Karaçam ${ }^{3}$, Ibrahim Meteoğlư \\ Osman Yılmaz ${ }^{5}$, Bahriye Oya Itil $^{1}$ \\ ${ }^{1}$ Chest Disease Department, Dokuz Eylül Üniversity, Izmir, Turkey \\ ${ }^{2}$ Chest Diseases Department, Muğla Sıtkı Koçman University, Mugla, Turkey \\ ${ }^{3}$ Chest Surgery Department, Dokuz Eylül University, Izmir, Turkey \\ ${ }^{4}$ Pathology Department, Adnan Menderese University, Aydin, Turkey \\ ${ }^{5}$ Laboratory Animal Science, Dokuz Eylül University, Izmir, Turkey \\ Kardiochir Torakochir Pol 2020; 17 (2): 65-69
}

\begin{abstract}
Introduction: Acute lung injury (ALI) and acute respiratory distress syndrome (ARDS) are acute onset syndromes affecting the lungs, which develop for several reasons and are characterized by hypoxemia and diffuse lung infiltration. The activity of thymoquinone (TQ) is known in acute lung injury. It is considered that it could be effective in ALI/ARDS treatment by ensuring possible COX-2 inhibition.

Aim: By this study was to show the protective activity of TQ in lipopolysaccharide (LPS) induced acute lung injury.

Material and methods: A total of $28 \mathrm{BALB} / \mathrm{c}$ male mice were randomized to 4 groups of 7 as the Control group, TQ group (3 mg/kg), LPS group ( $5 \mathrm{mg} / \mathrm{kg}$ ) and TQ treatment group. TQ was administered intraperitoneally 1 hour before the intratracheal administration of LPS $(5 \mathrm{mg} / \mathrm{kg})$. The mice were sacrificed 6 hours after the LPS administration and the lungs were extracted for histopathological examination. All experimental procedures complied with the requirements of the Animal Care and Ethics Committee of Dokuz Eylul University. Results: When all the study groups were compared, significant differences were found between the groups in terms of the degrees of neutrophil migration $(p=0.042)$, intra-alveolar hemorrhage $(p=0.004)$ and alveolar destruction $(p<0.0006)$. A significant recovery was observed in the lung histopathological changes (neutrophil migration, intra-alveolar hemorrhage and alveolar destruction) in the TQ treatment group.

Conclusions: The results of this study showed that TQ may have a protective effect against LPS-induced acute lung injury. The possible mechanism could be considered to be cyclooxygenase 2 (COX-2) inhibition.
\end{abstract}

Key words: acute lung injury, thymoquinone, lipopolysaccharide.

\section{Streszczenie}

Wprowadzenie: Ostre uszkodzenie płuc (ALI) i zespół ostrej niewydolności oddechowej (ARDS) stanowią dwa zespoły chorobowe o ostrym początku kończące się zajęciem płuc. Mogą mieć różne przyczyny i odznaczają się hipoksemią oraz obecnością rozlanych nacieków płucnych. Potwierdzoną aktywność w przebiegu ALI wykazuje tymochinon (TQ). Uważa się, że TQ może być skuteczny w leczeniu ALI lub ARDS dzięki mechanizmowi hamowania COX-2.

Cel pracy: Ocena ochronnego działania TQ w ALI wywołanym lipopolisacharydem (LPS).

Materiał i metody: Łącznie 28 samców myszy BALB/c przydzielono losowo do jednej z 4 grup po 7 osobników: grupy kontrolnej, grupy TQ (3 mg/kg), grupy LPS $(5 \mathrm{mg} / \mathrm{kg})$ i grupy TQ + LPS. TQ podawano dootrzewnowo 1 godzinę przed dotchawiczym podaniem LPS $(5 \mathrm{mg} / \mathrm{kg}$ ). Myszy uśmiercano po 6 godzinach od podania LPS i pobierano próbki z płuc do badania histopatologicznego. Wszystkie procedury doświadczalne były zgodne z zaleceniami Komisji ds. Dobrostanu Zwierząt i Etyki Uniwersytetu Dokuz Eylul.

Wyniki: Porównanie badanych grup wykazało istotne różnice pod względem stopnia migracji neutrofilów $(p=0,042)$, krwawienia wewnątrzpęcherzykowego $(p=0,004)$ i niszczenia pęcherzyków płucnych $(p<0,0006)$. W grupie otrzymującej TQ stwierdzono istotną poprawę pod względem płucnych zmian histopatologicznych (migracja neutrofilów, krwawienie wewnątrzpęcherzykowe i niszczenie pęcherzyków płucnych).

Wnioski: Wyniki badania wykazały, że TQ może mieć działanie ochronne, co zapobiega ALI wywołanemu przez LPS. Jako możliwy mechanizm wskazuje się hamowanie cyklooksygenazy 2 (COX-2).

Słowa kluczowe: ostre uszkodzenie płuc, tymochinon, lipopolisacharyd. 


\section{Introduction}

Acute lung injury (ALI) and acute respiratory distress syndrome (ARDS) are acute onset syndromes affecting the lungs directly or indirectly, which develop for several reasons and are characterized by hypoxemia and diffuse lung infiltration. Cases with an oxygenation rate of $\mathrm{PaO}_{2} / \mathrm{FiO}_{2} \leq 300$ are defined as $\mathrm{ALI}$, and those with an oxygenation rate of $\mathrm{PaO}_{2} / \mathrm{FiO}_{2} \leq 200$ are defined as ARDS [1]. ALI and ARDS are diseases with a poor prognosis often encountered in intensive care, which begin with moderate pulmonary function disorder and continue progressively and finally result in fatal pulmonary insufficiency $[2,3]$. Despite the recent increase in the number of studies conducted on intensive care patients and new therapeutic developments, ALI remains an important clinical problem with high mortality rates [4].

The chemical structure of thymoquinone (TQ) is $\mathrm{C} 10 \mathrm{H} 12 \mathrm{O} 2$ and it is a bioactive component obtained from nigella oil. TQ is known to have antihypertensive, antidiabetic, antibacterial, anti-inflammatory, neuroprotective and antiapoptotic effects [5-10]. TQ inhibits cyclooxygenase (COX) and 5-lipooxyenase pathways in arachidonic acid metabolism. It has been shown to inhibit thromboxane B2 and leukotriene B4 formations depending on the dosage [11]. COX-2 is an inducible form of COX and the level has been shown to increase in inflammation [12]. It has been demonstrated that COX-2 causes an increase in the inflammatory immune response in pulmonary damage [13]. The pharmacological inhibition of COX-2 has been determined to show protective activity against $A L I$ by causing a reduction in proinflammatory cytokines and chemokines [14]. The activity of TQ is known in lipopolysaccharide (LPS)-induced acute lung injury. It is considered that it could be effective in ALI/ARDS treatment by ensuring possible COX-2 inhibition.

\section{Aim \\ The purpose of this study was to research the protective activity of TQ in an LPS-induced ALI model. \\ Material and methods \\ Ethics statement \\ All experimental procedures have been validated with the protocol 88/2013 in accordance with the requirements of the Dokuz Eylul University Animal Care and Ethics Com- mittee.}

\section{Materials}

TQ was purchased from Sigma-Aldrich Inc. (MO, USA). LPS from Escherichia coli 055:B5 (Sigma-Aldrich, St. Louis, MO, USA) was used to induce ALI.

\section{Experimental design}

The study included $28 \mathrm{BALB} / \mathrm{C}$ male mice, aged 6-8 weeks, each weighing 20-32 g. The mice were kept at room temperature $\left(21-22^{\circ} \mathrm{C}\right)$ and $40-60 \%$ relative humidity in a 12-hour light and 12-hour dark environment and fed with standard pellet feed and water. The murine model used by
Shirley et al. was used in the study in order to create acute lung injury. A lipopolysaccharide-induced ALI model was created [15].

Anesthesia was ensured through intraperitoneal (ip) $50 \mathrm{mg} / \mathrm{kg}$ ketamine and $10 \mathrm{mg} / \mathrm{kg}$ xylazine for mice in all the groups. When necessary, maintenance ketamine (at half dose, $25 \mathrm{mg} / \mathrm{kg}$ ) was repeated according to the reflex responses (painful stimulant to foot via forceps - pedal reflex, palpebral and corneal reflexes) in order to maintain a stable anesthesia depth.

The mice were divided into 4 groups as group I $(n=7)$ to which intra-tracheal serum and intraperitoneal serum were administered physiologically, group II $(n=7)$ to which intraperitoneal $3 \mathrm{mg} / \mathrm{kg}$ TQ and intra-tracheal serum were administered physiologically, group III $(n=7)$ to which intra-tracheal $5 \mathrm{mg} / \mathrm{kg}$ LPS and intraperitoneal serum were administered physiologically, and group IV $(n=7)$ to which intra-tracheal $5 \mathrm{mg} / \mathrm{kg}$ LPS and intraperitoneal $3 \mathrm{mg} / \mathrm{kg}$ TQ were administered [7].

The intraperitoneal injection of TQ was applied 1 hour before the lipopolysaccharide application. Tissue samples were taken 6 hours after the lipopolysaccharide application [16]. The mice were sacrificed and the lungs were extracted. The tissue samples were fixed for 24 hours in $4 \%$ neutral buffered formalin. Sections of $4 \mu \mathrm{m}$ thickness were taken following the routine tissue follow-up procedure and stained with hematoxylin-eosin.

\section{Histological analysis}

The samples analyzed via light microscope were evaluated in terms of intra-arterial thrombus, neutrophils, intraalveolar hemorrhage, alveolar destruction, interstitial edema and hyaline membrane. The samples were graded as (-) if they had no symptoms and the samples showing symptoms were graded as mild $(+)$, moderate $(++)$ and severe $(+++)$ according to the condition. The evaluation was applied with the lung injury semi-quantitative scoring system suggested by Shields [17]. In this semi-quantitative scoring system, 0 indicated no change, 1+ focal mild changes, 2+ multifocal mild changes, and $3+$ diffuse severe changes.

\section{Statistical analysis}

The statistical analysis of the data was performed with the SPSS 15.0 program. Values were stated as mean, median, standard deviation and minimum and maximum. The Kruskal-Wallis test was performed to test the significance of the difference between the mean and 4 groups with no normal distribution. The Mann-Whitney $U$ test was used for pairwise comparison of the groups and all data were shown as mean \pm standard deviation (mean $\pm \mathrm{SD}$ ). A value of $p<0.05$ was accepted as statistically significant.

\section{Results}

The lung tissue sections of 28 mice were evaluated in terms of intra-arterial thrombus, neutrophil migration, intra-alveolar hemorrhage, alveolar destruction, interstitial edema and hyaline membrane symptoms. 


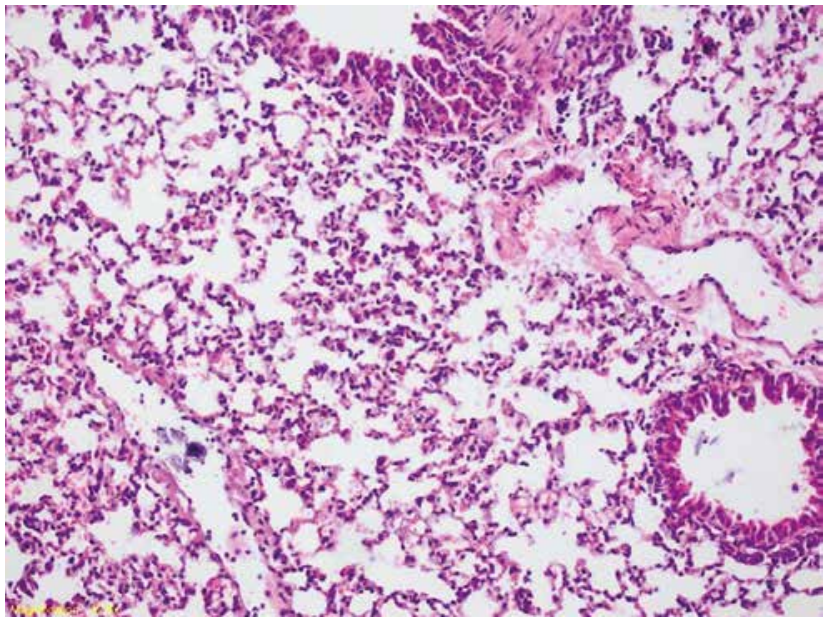

Figure 1. Group I normal lung tissue (HE, 100x)

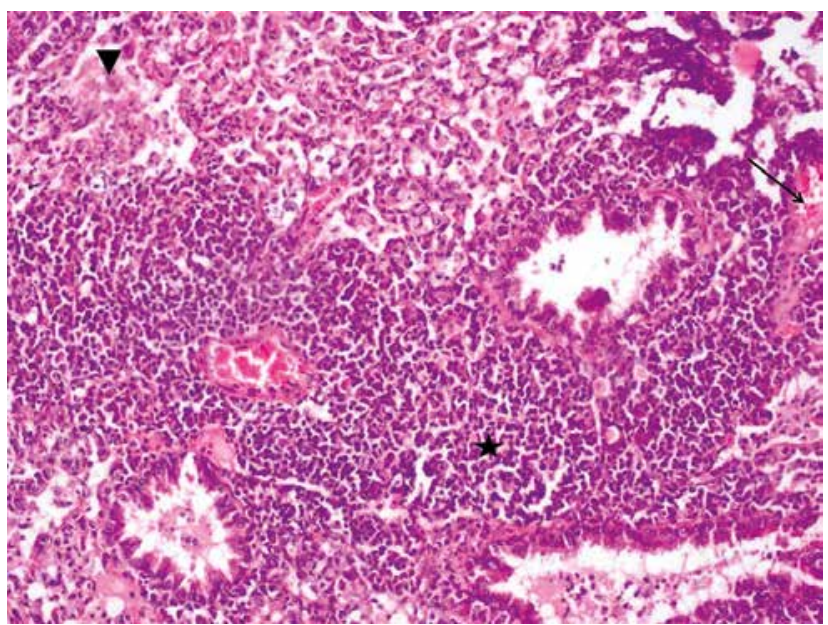

Figure 3. Group III very intense inflammation involving neutrophils (star), intra-alveolar hemorrhage (arrow) alveolar destruction and edema symptoms (arrowhead) (HE, 200x)

No intra-arterial thrombus, interstitial edema or hyaline membrane formation was determined in group I. It complied with normal lung tissue (Figure 1). Neutrophil migrations were determined in all cases in Group II and mild intra-alveolar hemorrhages were observed in almost half of the cases. The alveolar destruction was mild in almost all cases (Figure 2). Increases were seen in the degrees of neutrophil migration, intra-alveolar hemorrhage and alveolar destruction in group III compared to group I and group II

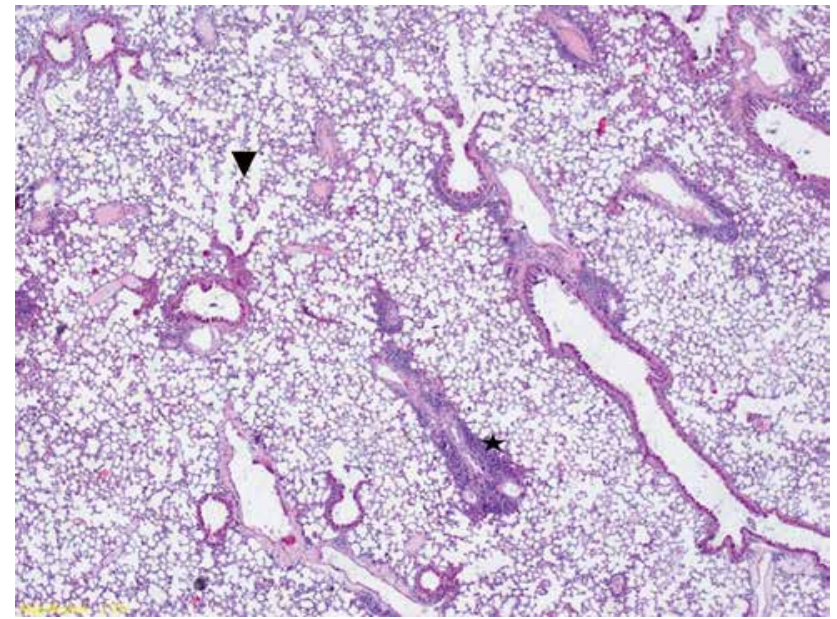

Figure 2. Group II slight injury in lung alveolar tissue (arrowhead), tissue increase in peribronchial area (star), focal neutrophilic infiltration symptoms (HE, 40x)

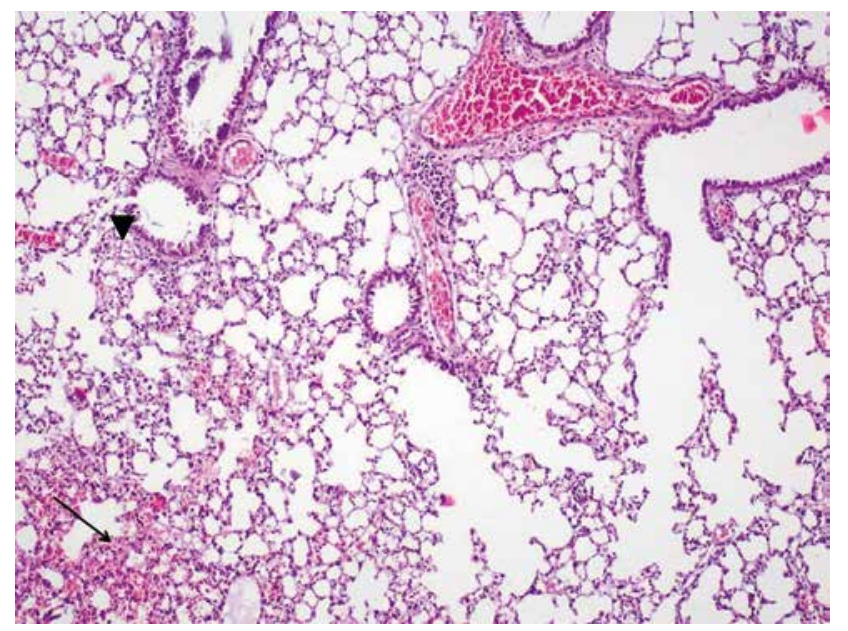

Figure 4. Group IV focal alveolar hemorrhage (arrow), focal slight edema symptoms (arrowhead) (HE, 100x)

(Figure 3). Decreases were seen in the degrees of neutrophil migration, intra-alveolar hemorrhage and alveolar destruction in group IV compared to group III (Figure 4). No hyaline membrane formation or intra-arterial thrombus was determined in any case. When all the study groups were compared, significant differences were found between the groups in terms of the degrees of neutrophil migration $(p=0.042)$, intra-alveolar hemorrhage $(p=0.004)$ and alveolar destruction $(p=0.0006)$ (Tables I, II).

Table I. Pathology results obtained in all study groups

\begin{tabular}{|c|c|c|c|c|c|c|}
\hline Group & $\begin{array}{c}\text { Intra-arterial } \\
\text { thrombus } \\
n(\%)\end{array}$ & $\begin{array}{c}\text { Neutrophil } \\
\text { migration } \\
n(\%)\end{array}$ & $\begin{array}{c}\text { Intra-alveolar } \\
\text { hemorrhage } \\
n(\%)\end{array}$ & $\begin{array}{c}\text { Alveolar } \\
\text { destruction } \\
n(\%)\end{array}$ & $\begin{array}{c}\text { Interstitial } \\
\text { edema } \\
n(\%)\end{array}$ & $\begin{array}{c}\text { Hyaline } \\
\text { membranes } \\
n(\%)\end{array}$ \\
\hline 1 & $0(0)$ & $3(42)$ & $3(42)$ & $3(42)$ & $0(0)$ & $0(0)$ \\
\hline 2 & $0(0)$ & 7 (100) & $4(57)$ & 7 (100) & $1(14)$ & $0(0)$ \\
\hline 3 & $1(14)$ & $6(85)$ & 7 (100) & 7 (100) & $2(28)$ & $0(0)$ \\
\hline \multirow[t]{2}{*}{4} & $0(0)$ & $6(85)$ & $2(28)$ & $3(42)$ & $1(14)$ & $0(0)$ \\
\hline & $p=0.91$ & $p=0.042$ & $p=0.004$ & $p=0.0006$ & $p=0.84$ & $p=1$ \\
\hline
\end{tabular}


Table II. Gradation of histopathological examinations

\begin{tabular}{lccc} 
Group & $\begin{array}{c}\text { Neutrophil } \\
\text { migration } \\
n(\%)\end{array}$ & $\begin{array}{c}\text { Intra-alveolar } \\
\text { hemorrhage } \\
n(\%)\end{array}$ & $\begin{array}{c}\text { Alveolar } \\
\text { estruction } \\
n(\%)\end{array}$ \\
\hline Group 1: & $\mathbf{3 ( 4 2 )}$ & $\mathbf{3 ( 4 2 )}$ & $\mathbf{3 ( 4 2 )}$ \\
\hline Mild & $3(42)$ & $3(42)$ & $3(42)$ \\
\hline Moderate & $0(0)$ & $0(0)$ & $0(0)$ \\
\hline Severe & $0(0)$ & $0(0)$ & $0(0)$ \\
\hline Group 2: & $7(100)$ & $4(57)$ & $7(100)$ \\
\hline Mild & $7(100)$ & $3(42)$ & $6(85)$ \\
\hline Moderate & $0(0)$ & $1(15)$ & $1(15)$ \\
\hline Severe & $0(0)$ & $0(0)$ & $0(0)$ \\
\hline Group 3: & $6(85)$ & $7(100)$ & $7(100)$ \\
\hline Mild & $3(42)$ & $2(71)$ & $0(0)$ \\
\hline Moderate & $2(28)$ & $5(29)$ & $4(57)$ \\
\hline Severe & $1(14)$ & $0(0)$ & $3(43)$ \\
\hline Group 4: & $6(85)$ & $2(28)$ & $3(42)$ \\
\hline Mild & $6(85)$ & $2(28)$ & $3(42)$ \\
\hline Moderate & $0(0)$ & $0(0)$ & $0(0)$ \\
\hline Severe & $0(0)$ & $0(0)$ & $0(0)$ \\
\hline$p=0.042$ & $p=0.004$ & $p=0.0006$ \\
\hline
\end{tabular}

\section{Discussion}

This experimental study analyzed the protective activity of TQ in LPS-induced lung injury. Apparent increases were determined in the degrees of neutrophil migration, intraalveolar hemorrhage and alveolar destruction in the LPS group compared to the other groups. The lung histopathology in the TQ treatment group showed similarities with the control group and the groups in which only TQ was administered. This is the first experimental study which shows the protective activity of TQ in LPS-induced lung injury. Although at a lesser degree in the present study, alveolar destruction, neutrophil migration and intra-alveolar hemorrhage were seen in Groups I and II and this was considered to be associated with the trauma created by the intratracheal injection.

Deterioration of the alveolar capillary membrane integrity, excessive transepithelial neutrophil migration and the release of pro-inflammatory, cytotoxic mediators, antiinflammatory cytokines, proteases and oxidants are the cellular characteristics of acute lung injury $[18,19]$. Active neutrophils release oxidant and proteolytic enzymes and these damage the basal membrane and epithelium cells $[20,21]$. Neutrophils settle in the lung interstitium in the proliferative phase and release mediators causing chemotaxis [22]. LPS, which is a structural component of the outer membrane of Gram-negative bacteria, acts potently to form ALI. Neutrophil-dependent ALI, which induces regional recruitment and activation of neutrophils, extrication of pro-inflammatory cytokines such as tumor necrosis factor (TNF)- $\alpha$, interleukin (IL)-1 $\beta$, and IL- 6 and the production of reactive oxygen and nitrogen species, is also known as LPSinduced ALI [16].

TQ is a bioactive monomer derived from black seed (Nigella sativa) oil, which has been reported to exhibit many pharmacological effects, including immunomodulatory, anticancer, antioxidant, and anti-inflammatory effects [23]. TQ inhibits the cyclooxygenase and 5-lipooxygenase pathways in the arachidonate metabolism. It has been shown to affect the formation of thromboxane B2 and leukotriene B4 by inhibition in a dose-related manner [7]. COX-2 is an inducible isoform of COX and it has been found at increasing levels during inflammation [12]. COX-2 has been shown to cause an increase in the inflammatory immune response in lung injury [13]. It has been determined that the pharmacological inhibition of COX-2 shows protective activity against ALI/ARDS by causing a decrease in proinflammatory cytokines and chemokines [14]. From the results of this study, TQ was considered to show protective activity against ALI through COX inhibition and antioxidant activities.

To the best of our knowledge, there has been no previous study in the literature which has analyzed TQ activity in LPS-induced acute lung injury. There is only one study, by Isık et al., which analyzed TQ activity in acute lung injury created in rats exposed to human intratracheal gastric juice [24]. In contrast to the present study, $6 \mathrm{mg} / \mathrm{kg}$ of TQ was administered to the rats and the model was created with human intratracheal gastric juice. Recoveries both in the oxygenation and lung histopathology were observed in the rats administered TQ in that study. However, no decrease in $\mathrm{CO}_{2}$ levels was observed, which was explained by insufficient ventilation of the group of rats administered TQ. There are some limitations associated with the present study. Electron microscopic examination could not be made and oxidant and antioxidant levels could not be observed in this study because of a lack of technical facilities.

The results of the present study showed the protective activity of TQ in LPS-induced lung injury. It is considered that this effect was achieved through antioxidant and COX-2 inhibition. With the inhibition of COX-2, leukotriene, thromboxane and prostaglandin formations are inhibited. Decreases are observed in neutrophil chemotaxis, vasoconstriction, bronchospasm and vascular permeability with the decrease of leukotriene formation. There will be a decrease in inflammatory cell infiltration with the decrease of neutrophil chemotaxis. However, the serine proteases, oxidants and matrix metalloproteinases released from neutrophils show a decrease, so the formation of tissue damage is prevented [11].

\section{Conclusions}

TQ may be a protective agent in acute lung injury. There is a need for further experimental and clinical studies to confirm these results.

\section{Disclosure}

Authors report no conflict of interest. 


\section{References}

1. Ashbaugh DG, Bigelow DB, Petty TL, et al. Acute respiratory distress in adults. Lancet 1967; 290: 319-323.

2. Bernard GR, Artigas A, Brigham KL, et al. The American-European Consensus Conference on ARDS. Definitions, mechanisms, relevant outcomes, and clinical trial coordination. Am J Respir Crit Care Med 1994; 149: 818-824.

3. Tomashefski JF. Pulmonary pathology of acute respiratory distress syndrome. Clin Chest Med 2000; 21: 435-466.

4. Bernard GR, Artigas A, Brigham KL, et al. Report of the American-European consensus conference on ARDS: definitions, mechanisms, relevant outcomes and clinical trial coordination. The Consensus Committee. Intensive Care Med 1994; 20: 225-232

5. Agarwal S, Reddy GV, Reddanna P. Eicosanoids in inflammation and cancer: the role of COX-2. Expert Rev Clin Immunol 2009; 5: 145-165.

6. El Thair KEH, Ashour MMS, Al-Harbi MM. The respiratory effects of the volatile oil of the black seed (Nigella sativa) in guinea pigs: elucidation of the mechanism(s) of action. Gen Pharmacol 1993; 24: 1115-1122.

7. Al-Gahmdi MS. The anti-inflammatory, analgesic and antipyretic activity of Nigella sativa. J Ethnopharmacol 2001; 76: 45-48.

8. El Tahir KEH, Ashour MMS, Al-Harbi MM. The cardiovascular actions of the volatile oil of the black seed (Nigella sativa) in rats: elucidation of the mechanism of action. Gen Pharmacol 1993; 24: 1123-1131.

9. Aboul-Ela El. Cytogenetic studies on Nigella sativa seeds extract and thymoquinone on mouse cells infected with schistosomiasis using karyotyping. Mutat Res 2002; 516: 11-17.

10. Turkdoğan MK, Ozbek H, Yener Z, et al. The role of Urtica dioica and Nigella sativa in the prevention of carbon tetrachloride-induced hepatotoxicity in rats. Phytother Res 2003; 17: 942-946.

11. Gilani A, Aziz N, Khurram I, et al. Bronchodilator, spasmolytic and calcium antagonist activities of Nigella sativa seeds (Kalonji): a traditional herbal product with multiple medicinal uses. J Pak Med Assoc 2001; 51: 115-120.

12. Zhang LN, Zheng JJ, Zhang L, et al. Protective effects of asiaticoside on septic lung injury in mice. Exp Toxicol Pathol 2011; 63: 519-525.
13. Jakubowski A, Maksimovich N, Olszanecki R, et al. S-nitroso human serum albumin given after LPS challenge reduces acute lung injury and prolongs survival in a rat model of endotoxemia. Naunyn Schmiedebergs Arch Pharmacol 2009; 379: 281-290.

14. Sio SW, Ang SF, Lu J, et al. Substance $P$ upregulates cyclooxygenase- 2 and remote acute lung injury. J Immunol 2010; 185: 6265-6276.

15. Mei SHJ, McCarter SD, Deng Y, et al. Prevention of LPS-induced acute lung injuryin mice by mesenchymal stem cells overexpressing angiopoietin 1. PLoS Med 2007; 4: e-269.

16. Kalemci S, Zeybek A, Intepe YS, et al. Methyl palmitate attenuates lipopolysaccharide-induced acute lung injury in mice. Clin Ter 2013; 164: 453-459.

17. Shields CJ, Winter DC, Manning BJ, et al. Hypertonic saline perfusion for pulmonary injury due to ischemia-reperfusion. Arch Surg 2003; 138: 9-14.

18. Ichikado K, Suga M, Gushima Y, et al. Hyperoxia-induced diffuse alveolar damage in pigs: correlationbetween thin-section $\mathrm{CT}$ and histopathologic findings. Radiology 2000; 216: 531-538.

19. Matthay MA, Zimmerman GA. Acute lung injury and the acute respiratory distress syndrome: four decades of inquiry into pathogenesis and rational management. Am J Respir Cell Mol Biol 2005; 33: 319-327.

20. Ginzberg HH, Cherapanov V, Dong Q, et al. Neutrophil-mediated epithelial injury during transmigration: role of elastase. Am J Physiol Gastrointest Liver Physiol 2001; 281: 705-717.

21. Matute-Bello G, Martin TR. Science review: apoptosis in acute lung injury. Crit Care 2003; 7: 355-358

22. Tomashefski JF Jr. Pulmonary pathology of acute respiratory distress syndrome. Clin Chest Med 2000; 21: 435-466.

23. Salem ML. Immunomodulatory and therapeutic properties of the Nigella sativa L.seed. Int Immunopharmacol. 2005; 5: 1749-1770.

24. Isık AF, Kati I, Bayram I, at al. A new agent treatment of acute respiratory distress syndrome: thymoquinone. An experimental study in a rat model. Eur J Cardiothorac Surg 2005; 28: 301-305. 